\begin{tabular}{|l|l|l|l|l|l|}
\hline J. Tek. Ling & Vol. 13 & No. 1 & Hal. $109-121$ & Jakarta, Januari 2012 & ISSN 1441-318X \\
\hline
\end{tabular}

\title{
ANALISIS VIABILITAS PROBIOTIK Lactobacillus TERENKAPSULASI DALAM PENYALUT DEKSTRIN DAN JUS MARKISA (Passiflora edulis)
}

\author{
Titin Yulinery dan N. Nurhidayat \\ Peneliti di Bidang Mikrobiologi, P2B LIPI. \\ Jl.Raya Bogor - Jakarta km 46 cibinong
}

\begin{abstract}
Abstrak
Probiotik cair tidak efisien dalam stabilitas dan kemasan. Bubuk probiotik dapat disimpan lebih lama dan stabilitas dalam kualitas. Bubuk bisa dibuat dengan metode enkapsulasi sedangkan konsentrasi lapisan sangat penting. Rasa dari bubuk seperti jus markisa yang diperlukan untuk mendapatkan rasa bagus di minum. Penelitian ini menggunakan L. plantarum dan Lactobacillus Mar 8 A17 dengan menambahkan gairah jus buah dan dekstrin dengan konsentrasi beberapa seperti $2 \%, 5 \%, 10 \%$ dan $15 \%$. Kemudian dikemas dengan menggunakan spray dryer pada $125^{\circ} \mathrm{C}$. Bubuk dari enkapsulasi disimpan selama 2 minggu pada suhu $4^{\circ} \mathrm{C}$, tahapan uji coba telah dilakukan untuk bedak sebelum dan setelah enkapsulasi setelah disimpan selama 2 minggu pada suhu $4^{\circ} \mathrm{C}$. Setelah enkapsulasi bahwa berat tertinggi pada pengobatan dengan menggunakan jus buah gairah Lactobacillus A17 dengan dekstrin 15\% adalah 5649,6 mg dan diikuti oleh $L$. plantarum Mar8 adalah $5400 \mathrm{mg}$. Kelangsungan hidup setelah enkapsulasi untuk setiap konsentrasi dekstrin yang signifikan, kecuali pada konsentrasi $10 \%$ tidak signifikan, tapi di gudang untuk penyimpanan dua minggu setelah enkapsulasi kelangsungan hidup Lactobacillus plantarum Mar8 dan A17 Lactobacillus signifikan. yaitu 8,59 log10 cfu / g dan 7,28 log10cfu / g. Penyimpanan setiap sampel adalah variasi, tetapi Lactobacillus A17 dengan dekstrin 10\% dapat disimpan sampai 72,02 hari dan tingkat mortalitas adalah 0,00141 cfu / g / jam, sedangkan L.plantarum Mar8 bisa menjadi toko hanya sampai 14,63 hari dan tingkat mortalitas adalah 0,00867 cfu / g / jam. Jadi, perawatan ini dengan menambahkan jus markisa dengan dekstrin 10\% dapat direkomendasikan sebagai probiotik dalam bentuk bubuk
\end{abstract}

kata kunci: Lactobacillus, enkapsulasi, dekstrin, gairah jus buah

\begin{abstract}
The liquid probiotic is not efficient in stability and packaging. The powder probiotic could be kept longer and stability in quality. Powder could be made by encapsulation method while the concentration of coating is very important. The flavor of the powder like passion fruit juice was needed to get the nice taste in drinking. This research used L. plantarum Mar 8 and Lactobacillus A17 by adding passion fruit juice and dextrin with several concentration like $2 \%, 5 \%, 10 \%$ and $15 \%$. Then encapsulated by using spray dryer at $125^{\circ} \mathrm{C}$. The powder of encapsulation stored for 2 weeks at $4^{\circ} \mathrm{C}$, viability test had been done to the powder before and after encapsulation after stored for 2 weeks at $40 C$. After encapsulation that the highest weight on the treatment by using passion fruit juice of Lactobacillus A17 with $15 \%$ dextrin was $5649.6 \mathrm{mg}$ and followed by L. plantarum Mar8 was $5400 \mathrm{mg}$. The viability after encapsulation for each dextrin concentration was significant, except at $10 \%$ concentration was not significant, but in storage for two
\end{abstract}


weeks storage after encapsulation the viability of Lactobacillus plantarum Mar8 and Lactobacillus A17 was significant. ie, $8.59 \log 10 \mathrm{cfu} / \mathrm{g}$ and $7.28 \mathrm{log} 10 \mathrm{cfu} / \mathrm{g}$. The storage of each sample were variation, but Lactobacillus $A 17$ with $10 \%$ dextrin could be stored until 72.02 days and the mortality rate was $0.00141 \mathrm{cfu} / \mathrm{g} / \mathrm{hour}$, while L.plantarum Mar8 could be store only until 14.63 days and the mortality rate was $0,00867 \mathrm{cfu} / \mathrm{g} / \mathrm{hour}$. So, this treatment by adding passion fruit juice with $10 \%$ dextrin could be recommended as probiotic in powder forms

key words : Lactobacillus, encapsulation, dextrin, passion fruit juice

\section{PENDAHULUAN}

\subsection{Latar Belakang}

Organisasi kesehatan dunia memberikan implementasi untuk mencari alternatif strategis sebagai pengobatan yang potensial untuk mengontrol penyakit seperti bakteri probiotik ${ }^{1)}$. Bakteri asam laktat secara umum digunakan dalam fermentasi makanan dan minuman yang kontribusinya sebagai sensor kualitas makanan dan pencegahan spoilage ${ }^{2}$. Probiotik merupakan bakteri hidup nonpatogen yang diasup setiap hari sebagai suplemen makanan sehingga terjaga keseimbangan dalam ekosistem mikrobiota usus dapat menguntungkan kesehatan tubuh ${ }^{3)}$, sehingga memperkuat sistem imunitas antara lain meningkatkan jumlah limfo-B dalam pelat peyer, yang merupakan pusat dari sistem ketahanan tubuh di usus halus ${ }^{4}$, menurunkan jumlah bakteri patogen dengan memproduksi komponen anti bakteri serta melakukan kompetisi untuk memperoleh daerah kolonisasi5. Hasil penelitian membuktikan bahwa bakteri probiotik tahan terhadap asam lambung dan asam empedu sehingga mampu mencapai usus dalam keadaan hidup ${ }^{6}$. Probiotik beradhesi (melekat) dan membentuk koloni pada permukaan usus sehingga dapat menstimulir sistem imun dengan meningkatkan aktivitas makrofag ${ }^{7}$.

Probiotik bermacam-macam jenisnya, namun berbeda pada efek immunomodulasiny ${ }^{8)}$, namun memiliki fungsi yang sama yakni menjaga keseimbangan mikroflora dalam usus, salah satunya adalah Lactobacillus plantarum. L. plantarum termasuk ke dalam bakteri asam laktat yang dapat digunakan sebagai probiotik ${ }^{7}$.

L. plantarum termasuk dalam famili Lactobacillaceae ${ }^{9}$, menghasilkan asam laktat $>85 \%$ sehingga dikategorikan bakteri asam laktat homofermentatif ${ }^{7}$, tumbuh baik pada suhu $37^{\circ} \mathrm{C}$ (mesofil) ${ }^{10}$ ) dengan $\mathrm{pH}$ optimum 4-6 ${ }^{11}$. Bakteri ini memiliki sifat katalase negatif, aerob atau fakultatif anaerob, cepat mencerna protein, toleran terhadap asam. L. plantarum cenderung berbentuk batang pendek dalam kondisi pertumbuhan yang sesuai dan cenderung lebih panjang di bawah kondisi yang tidak menguntungkan, mempunyai kemampuan menghasilkan bakteriosin, merupakan senyawa polipeptida atau protein yang bersifat bakterisidal. Hal tersebut diperkuat oleh James et al. ${ }^{12)}$ yang menyatakan bahwa L. plantarum merupakan bakteri penghasil hidrogen peroksida tertinggi dibandingkan bakteri asam laktat lainnya. Berdasarkan hasil penelitiannya ${ }^{13)}$ L.plantarum mempunyai daerah penghambat terbesar terhadap Listeria monocytogenes dibandingkan dengan bakteri asam laktat lainnya, sedangkan ${ }^{14)}$ mengatakan bahwa L. plantarum $299 \mathrm{v}$ dapat meningkatkan konsentrasi asam karbosilik pada feses, mencegah iritasi usus dan menurunkan konsentrasi fibrinogen dalam darah sehingga mengurangi faktor resiko thrombosis.

Probiotik yang beredar dipasaran kebanyakan dalam bentuk sediaan cair, namun kurang efisien dalam hal stabilitas (kadaluarsa, penyimpanan) maupun dalam pengemasan ${ }^{15}$, disamping itu kemungkinan untuk ditumbuhi bakteri lain lebih besar dibandingkan dalam bentuk serbuk, oleh karena itu perlu dibuat sediaan dalam 
bentuk padat. Industri penghasil probiotik mengimpor bakteri nonpatogen dalam bentuk serbuk dari luar negeri, hal inilah yang menyebabkan mahalnya harga probiotik. Bila probiotik ini dapat dibuat sendiri tanpa harus mengimpor dari luar negeri maka harganya akan lebih murah dan dapat dikonsumsi oleh masyarakat menengah kebawah.

Salah satu alternatif untuk pengawetan kultur adalah dengan pengeringan. Pengeringan bertujuan untuk memperpanjang daya simpan, mem permudah distribusi dan memudahkan pemeliharaan .

Menurut ${ }^{16)}$, enkapsulasi memberikan sarana untuk mengubah komponen dalam bentuk cair menjadi partikel padat dan melindungi materi dari pengaruh lingkungan.

Pembuatan sediaan serbuk bakteri ini dapat dilakukan dengan metoda spray-drying atau pengeringan semprot yaitu dengan menggunakan uap panas dimana kandungan air akan mengering dan mengubah bahan menjadi serbuk ${ }^{17)}$, sering digunakan untuk bahan-bahan makanan yang berbentuk cairan atau pasta dengan viskositas rendah. Pengeringan semprot dapat menghasilkan produk yang berkualitas tinggi, terutama untuk bahanbahan yang sensitif terhadap panas. Hal ini disebabkan oleh proses atomisasinya yang menggunakan sejumlah udara ${ }^{18)}$. Selain pengeringan semprot pengeringan beku (freeze dryer (pengeringan beku) dapat digunakan, namun prosesnya sedikit rumit karena membutuhkan ruang beku dan vakum $^{19)}$.

Penambahan bahan pengisi perlu dilakukan untuk menurunkan kecenderungan bubuk melekat pada dinding pengering. Salah satu bahan penyalut yang digunakan untuk pengeringan semprot adalah dektrin. Dekstrin merupakan material hasil degradasi pati yang mempunyai viskositas yang rendah. Viskositas yang rendah dari dektrin penting untuk pembuatan dan pengeringan lapisan tipis $^{20)}$. mudah larut dalam air mendidih, membentuk larutan mucilago, hampir tidak larut dalam alkohol, chloroform, eter, banyak digunakan di industri-industri sebagai bahan pengikat dan bahan pengental ${ }^{21)}$.

Penambahan jus markisa (Passiflora edulis) digunakan sebagai komponen penambah rasa sehingga dapat dihasilkan probiotik dalam bentuk sediaan padat dengan rasa yang enak dan harga yang lebih terjangkau. Markisa merupakan salah satu jenis buah-buahan yang termasuk keluarga Passifloraceae. Buah markisa banyak dibudidayakan di Sumatra Utara dan Sulawesi Selatan yang buahnya diolah menjadi sirup secara komersial ${ }^{22)}$.

Dengan menggunakan spray-dryer, seluruh air dari bahan yang akan dikeringkan diubah dalam bentuk butiran-butiran air dengan cara diuapkan menggunakan atomizer. Air dari bahan yang telah berbentuk tetesan-tetesan tersebut kemudian dikontakkan dengan udara panas. Peristiwa pengontakan ini menyebabkan air dalam bentuk tetesan-tetesan mengering dan berubah menjadi serbuk. Selanjutnya proses pemisahan antara uap panas dengan serbuk dilakukan dengan cyclone atau penyaring, setelah dipisahkan, suhu kembali diturunkan sesuai dengan kebutuhan produksi ${ }^{17)}$.

Viabel atau viabilitas merupakan jumlah sel yang dapat hidup biasanya diperkirakan sebagai ukuran konsentrasi sel ${ }^{23)}$. Viabilitas kultur kering selama penyimpanan dipengaruhi oleh suhu penyimpanan dan bahan pengemas yang digunakan ${ }^{24}$. Kultur kering bakteri asam laktat yang disimpan pada suhu dingin $\left(4^{\circ} \mathrm{C}\right)$ mempunyai viabilitas yang lebih tinggi dibandingkan dengan kultur kering yang disimpan pada suhu kamar ${ }^{25)}$. Penyimpanan kultur kering pada suhu kamar sangat tidak direkomendasikan, apapun jenis pengeringannya (Spray/Freeze drying) karena kultur bakteri asam laktat (BAL) lebih stabil disimpan pada suhu dingin.

Tujuan dari penelitian ini adalah untuk mengetahui konsentrasi dekstrin yang optimal sebagai penyalut dan pelindung Lactobacilus dalam jus markisa sehingga menghasilkan viabilitas yang tinggi dan daya terima yang baik dalam masyarakat. 
Memberi informasi kepada para pelaku industri farmasi bahwa pembuatan serbuk Lactobacilus dapat dilakukan dengan metoda spray-drying dan dengan penambahan dekstrin sebagai bahan penyalut.

\section{METODOLOGI}

\subsection{Peremajaan Lactobacillus sebagai kultur induk}

Isolat Lactobacillus plantarum Mar 8 dan Lactobacillus A17 diisolasi dari buah markisa (Medan), merupakan koleksi Lab. Genetika, Bidang Mikrobiologi, LIPI. Sebelum digunakan untuk dienkapsulasi dan setelah enkapsulasi, isolat isolat tersebut dilakukan pengujian seperti di bawah ini

\subsection{Uji Zona Bening}

Isolat ditumbuhkan pada media GYP yang mengandung glukosa $10 \mathrm{~g}$, yeast extract $10 \mathrm{~g}$, Tripton $10 \mathrm{~g}$, Natrium asetat anhidrat $1,4 \mathrm{~g}$, beef extract $2 \mathrm{~g}$, tween 8010 $\mathrm{ml}$, Salt solution $5 \mathrm{ml}$ ( natrium klorida $0,1 \mathrm{~g}$, $\mathrm{MgSO}_{4} \cdot 7 \mathrm{H}_{2} \mathrm{O} 0,1 \mathrm{~g}$, Feri Sulfat anhidrat 0,1 $\mathrm{g}$ ), agar $20 \mathrm{~g}$, dilarutkan dalam $1 \mathrm{~L}$ akuades lalu disterilisasi dengan autoklaf. Dilakukan penambahan $\mathrm{CaCO}_{3}$ sebanyak 0,5\% pada media GYP padat yang digunakan sebagai media pemupukan. Isolat yang tumbuh sebagai Lactobacillus akan membentuk zona bening disekitar koloni.

\subsection{Uji Katalase}

Satu ose koloni yang terbentuk pada media GYP padat digoreskan pada sebuah kaca objek yang telah diberi satu tetes $\mathrm{H}_{2} \mathrm{O}_{2} 3 \%$. Kemudian diamati terbentuknya gelembung gas pada koloni dan sekitarnya. Jika terdapat gelembung gas menandakan uji katalase tersebut positifer). Lactobacillus akan menunjukkan katalase negatif.

\subsection{Uji Pewarnaan Gram}

Preparat ulas bakteri dari koloni yang akan di uji dibuat pada kaca objek, difiksasi diatas api bunsen. Preparat ditetesi dengan satu tetes larutan kristal violet, didiamkan gu dan negatif jika sel berwarna merah ${ }^{27)}$. Lactobacillus didiamkan selama 60 detik, dan dicuci dengan akuades. Preparat ditetesi lagi dengan satu tetes larutan lugol, dibiarkan selama 30 detik, dan dicuci dengan akuades. Preparat kemudian ditetesi dengan satu tetes etanol $70 \%$, lalu didiamkan lagi selama 30 detik, kemudian dicuci dengan akuades. Preparat ditetesi dengan satu tetes safranin, didiamkan selama 30 detik, dan dicuci dengan akuades. Terakhir preparat dikeringkan dan ditetesi dengan minyak imersi, lalu diamati dengan mikroskop. Uji gram positif jika sel berwarna ungu dan negatif jika sel berwarna merah ). $L$. plantarum akan memperlihatkan bentuk batang dan warna ungu (gram positif) ${ }^{27)}$.

\subsection{Preparasi sampel control}

Dipilih buah markisa yang matang dan segar, lalu disortasi basah dengan air mengalir dan tiriskan. Dibuat jus markisa dengan perbandingan $1: 3$ yakni $25 \mathrm{~mL}$ sari markisa ditambahkan $75 \mathrm{~mL}$ akuades. Kemudian dimasukkan dekstrin $10 \%$ lalu dicampur hingga homogen (dilakukan pengukuran $\mathrm{pH}$ ). Campuran disterilkan dalam autoklaf pada suhu $121^{\circ} \mathrm{C}$ dengan tekanan 1 atm selama 20 menit. Setelah itu dimasukkan ke dalam spray-dryer pada suhu $125^{\circ} \mathrm{C}$

\subsection{Preparasi sampel untuk encap sulasi}

Lactobacillus diinokulasi dalam 100 $\mathrm{mL}$ media GYP Broth lalu diinkubasi selama 48 jam pada suhu $37^{\circ} \mathrm{C}$ (Kultur Induk). Sebanyak $10 \mathrm{~mL}$ L. plantarum Mar 8 dan A 17 dari kultur induk diinokulasi ke dalam media GYP Broth masing masing $100 \mathrm{~mL}$ lalu diiinkubasi selama 48 jam pada suhu $37^{\circ} \mathrm{C}$. Setelah diinkubasi, diambil peletnya dengan cara disentrifugasi pada kecepatan 10.000 rpm selama 10 menit. Kemudian pelet dicuci dengan akuades steril dan disentrifugasi kembali.

Dibuat $100 \mathrm{~mL}$ sari markisa yang telah diencerkan dengan akuades dengan perbandingan 1:3 dan mengandung dekstrin 
dengan konsentrasi $2 \%, 5 \%, 10 \%$, dan $15 \%$ , kemudian disterilisasi dengan autoklaf pada suhu $121^{\circ} \mathrm{C}$ dengan tekanan 1 atm selama 20 menit (dilakukan pengukuran $\mathrm{pH}$ sebelum proses sterilisasi). Pelet Lactobacillus siap untuk ditambahkan ke dalam jus markisa tersebut.

Sebanyak $1 \mathrm{~mL}$ dari masing-masing sampel disimpan dalam eppendorf untuk keperluan analisis viabilitas sebelum enkapsulasi. Sisa sampel dienkapsulasi dengan spray-dryer pada suhu inlet $125^{\circ} \mathrm{C}$ sampai diperoleh masa berbentuk serbuk. Setelah selesai enkapsulasi probiotik Lactobacillus, lalu diuji viabilitasnya

dengan cara ditanam segera setelah enkapsulasi. Sisa enkapsulasi disimpan pada suhu $4^{\circ} \mathrm{C}$ dan didiamkan selama 2 minggu untuk uji viabilitas tahap selanjutnya. Uji viabilitas dilakukan duplo. Dilakukan secara aseptik.

\subsection{Uji Viabilitas Lactobacillus}

Untuk analisis viabilitas sebelum enkapsulasi, diambil sebanyak $100 \mu \mathrm{L}$ dan untuk analisis viabilitas segera setelah enkapsulasi dan dua minggu setelah enkapsulasi, diambil sebanyak $0,1 \mathrm{~g}$ serbuk hasil spray-dryer, masing-masing dibuat pengenceran secara seri sampai 107 dengan larutan $\mathrm{NaCl}$ fisiologis $(0,85 \%)$ dan dihomogenkan. Setelah itu sebanyak $100 \mu \mathrm{L}$ dimasukkan ke dalam cawan petri steril yang sudah berisi media GYP padat $+\mathrm{CaCO}_{3}$. Kemudian inkubasi selama 48 jam pada suhu $37^{\circ} \mathrm{C}$. Dihitung koloni tumbuh $(\mathrm{Cfu} / \mathrm{mL})$

\subsection{Analisis Data}

Untuk menentukan waktu simpan sel (t) dalam satuan $\mathrm{Cfu/g/jam} \mathrm{dan} \mathrm{laju}$ kematian sel (k) (hingga mencapai jumlah sel $10^{6} \mathrm{Cfu} / \mathrm{g}$ terenkapsulasi menggunakan persamaan :

$$
\left|\log N_{2}-\log N_{1}\right|=k(t) / 2,303
$$

Keterangan:
Log N1 = Logaritma rata-rata viabilitas setelah enkapsulasi

Log N2 = Logaritma rata-rata viabilitas 2 minggu setelah enkapsulasi

$\mathrm{k}=$ Laju kematian per jam

$\mathrm{t}=$ Waktu penyimpanan

Data hasil penelitian dianalisis dengan menggunakan Statistical Package For The Social Sciences (SPSS) For Window v.10.0 untuk mengetahui adanya perbedaan dari tiap perlakuan.

\section{HASIL DAN PEMBAHASAN}

\subsection{Hasil Enkapsulasi}

Pembuatan sediaan serbuk bakteri dilakukan dengan metoda spray-drying atau pengeringan semprot yaitu dengan menggunakan uap panas sehingga kandungan air akan mengering dan mengubah bahan menjadi serbuk ${ }^{17)}$. Hasil enkapsulasi dengan penambahan konsentrasi dekstrin yang berbeda akan menghasilkan serbuk dengan berat dan karakteristik serbuk yang berbeda. Pada Tabel 1 terlihat bahwa bobot yang paling tinggi dari hasil enkapsulasi yaitu pada L. plantarum Mar 8+dekstrin 10\% (tanpa jus markisa) sebesar $5823,8 \mathrm{mg}$ (nilai rendemen sebesar $52,24 \%$ ), sedangkan bobot yang tertinggi menggunakan jus markisa yakni pada perlakuan Lactobacillus A17+dekstrin 15\% dan diikuti dengan perlakuan $L$. plantarum Mar8 +dekstrin $15 \%$ yakni 5649,6 mg (nilai rendemen sebesar 36,48\%) dan $5400 \mathrm{mg}$ (nilai rendemen sebesar 33,96\%). Bobot perlakuan dengan penambahan jus markisa lebih rendah tanpa jus markisa, disebabkan karena selama proses enkapsulasi penambahan jus markisa membuat sediaan menjadi lebih lengket akibat panas yang ditimbulkan pada saat enkapsulasi sehingga banyak yang tertinggal pada alat spray dryer, selain itu jumlah penyalut yang dimasukkan berpengaruh terhadap jumlah serbuk yang dihasilkan. Enkapsulasi mengubah komponen dalam bentuk cairan menjadi partikel padat dan melindungi materi 
dari pengaruh lingkungan ${ }^{16)}$. Penggunaan dekstrin $10 \%$ dan suhu inlet spray-drying $125^{\circ} \mathrm{C}$ akan menghasilkan kualitas bubuk yang baik secara fisika, kimia dan organoleptik. Hal lain yang dapat mempengaruhi berkurangnya bobot hasil serbuk adalah proses enkapsulasi, dimana dalam setiap proses dapat terjadi kesalahan seperti kenaikan suhu dikarenakan pemampatan pada alat semprot (Noozle).

Dari grafik hasil rendemen (Gambar 1) menunjukkan bahwa tingginya nilai rendemen tidak hanya ditentukan oleh banyaknya jumlah serbuk hasil enkapsulasi yang diperoleh, tetapi perbandingan antara jumlah padatan yang ditambahkan pada larutan yang akan dienkapsulasi dengan serbuk hasil enkapsulasi tidak berbeda jauh. Pada Lactobacillus A17 dengan konsentrasi dekstrin 5\% (H) menunjukkan nilai rendemen tertinggi yaitu sebesar $86,928 \%$. Hal tersebut dikarenakan penurunan berat padatan sebelum dan sesudah dienkapsulasi hanya berkurang sedikit. Sedangkan tanpa jus markisa menghasilkan serbuk terbanyak dan nilai rendemen yang dihasilkan tidak terlalu tinggi. Hal ini dikarenakan berat padatan sesudah dienkapsulasi menurun setengahnya dari berat awal.

Penambahan dekstrin pada proses enkapsulasi menghasilkan serbuk yang bervariasi, dimana serbuk tersebut memiliki bentuk yang berbeda terlihat seperti butiran sangat kecil dan berwarna putih pada L. plantarum Mar $8+$ dekstrin $10 \%$ dan pada konsentrasi dekstrin $15 \%$ butiran berwarna kuning pucat. Pada kontrol dan konsentrasi dekstrin 10\% butiran lebih besar dan saling melekat, berwarna kekuningkuningan. Konsentrasi dekstrin 2\% dan 5\% tidak menghasilkan serbuk pada proses enkapsulasi dikarenakan dekstrin yang ditambahkan sebagai penyalut terlalu sedikit.

Untuk mengetahui kualitas dari hasil enkapsulasi maka dilakukan uji organoleptik. Hasil dari uji organoleptik menunjukkan semakin rendah konsentrasi dekstrin yang ditambahkan maka serbuk yang dihasilkan akan semakin lengket, rasanya pun akan lebih asam dan memiliki warna yang semakin kuning.

\subsection{Hasil Uji Organoleptik}

Perlakuan Markisa + L. plantarum Mar 8 dan A17 + Dekstrin 5\% memberikan rasa sangat asam, lebih asam dibandingkan dengan penambahan dekstrin $10 \%$ dan $15 \%$, berwarna kuning tua dan beraroma sangat menyengat (segar). Hal tersebut dikarenakan konsentrasi jus markisa lebih banyak dibandingkan dengan konsentrasi dekstrin. Struktur lengket seperti dodol atau gulali, saling menempel dan sulit untuk dipisahkan. Ini disebab karena kandungan dekstrin sebagai penyalut sangat sedikit, sehingga serbuk saling menempel dan tidak kering dengan sempurna sehingga nilai estetika kurang.

Markisa + L. plantarum Mar 8 dan A17 + Dekstrin 10\% memberikan Rasa sedikit asam, warna serbuk kuning muda aromanya terasa segar. Hal tersebut dikarenakan penambahan dekstrin dengan konsentrasi optimal. Struktur halus dan lembut dilidah, namun tidak sehalus struktur pada penambahan dekstrin $15 \%$. Kelarutan sangat baik, bersifat higroskopis dan nilai estetika baik.

Markisa + L. plantarum Mar 8 dan A17+ Dekstrin $15 \%$ mempunyai rasa kurang asam, warna serbuk putih pucat, beraroma kurang segar. Hal tersebut disebabkan karena penambahan dekstrin yang terlalu banyak menyebabkan prodak didominasis oleh dekstrin sehingga sari dari markisa tertutup oleh dekstrin. Struktur sangat halus dan lembut dilidah, namun tidak sehalus struktur pada penambahan dekstrin $15 \%$, kelarutan sangat baik bersifat higroskopis dan nilai estetika kurang.

L. plantarum Mar $8+$ Dekstrin 15\% rasanya sedikit manis, warna serbuk putih, aroma tidak segar. Struktur sangat halus dan lembut dilidah, kelarutan sangat baik, bersifat higroskopis dan nilai estetika kurang.

Markisa + Dekstrin 10\% (Kontrol 
Negatif) Rasa sama seperti pada markisa + L. plantarum Mar 8 (A17) + Dekstrin $10 \%$. Pada uji organoleptik penambahan $L$. plantarum Mar 8 atau A17 tidak merubah rasa produk.

\subsection{Hasil Uji Viabilitas}

Analisis viabilitas yang diperoleh dari hasil penghitungan koloni Lactobacillus pada tiap perlakuan menunjukan bahwa jus markisa dan dekstrin dapat mempengaruhi jumlah viabilitas dari L. plantarum Mar 8 dan A17 dengan hasil viabilitas yang berbeda untuk tiap perlakuan. Hasil perhitungan menunjukkan bahwa hampir semua perlakuan menghasilkan viabilitas setelah enkapsulasi sebesar $10^{7} \mathrm{Cfu} / \mathrm{g}$,- jumlah tersebut masih memenuhi syarat sebagai probiotik, kecuali pada konsentrasi dekstrin $2 \%$ dengan kultur L. plantarum Mar 8 tidak memenuhi syarat karena tidak ada viabilitas sama sekali. Jumlah minimum bakteri yang dapat digunakan sebagai probiotik tidak kurang dari $10^{6}$ CFU per gram ${ }^{28)}$, Namun sebaiknya viabilitas lebih dari $10^{6}$ CFU per gram dikarenakan kemungkinan berkurangnya viabilitasnya akibat lamanya penyimpanan.

Pengujian viabilitas L. plantarum Mar 8 dan A 17 sebelum enkapsulasi, segera setelah enkapsulasi, dan 2 minggu setelah enkapsulasi, dapat dilihat pada Tabel 2. di bawah ini.

Data hasil perhitungan Colony Forming Unit (cfu/g) setelah di logaritmakan untuk dibuat dalam bentuk grafik.

Dari grafik (Gambar 2.) menunjukkan L.plantarum Mar8 + Dekstrin 10\% (tanpa jus markisa) menghasilkan nilai rata-rata Log jumlah viabilitas setelah enkapsulasi dan 2 minggu setelah enkapsulasi yang lebih tinggi dibandingkan dengan semua perlakuan yakni sebesar 8,312 Log10 Cfu/g dan nilai rata-rata Log jumlah viabilitas 2 minggu setelah enkapsulasi sebesar 9,275 Log10 Cfu/g. Hal ini disebabkan karena penambahan jus markisa dapat menurunkan
$\mathrm{pH}$ (lebih asam) sehingga mempengaruhi kemampuan Lactobacillus Mar 8 dan A17 dalam bertahan hidup ( $\mathrm{pH}$ markisa 2,8-3). Lactobacillus dapat tumbuh pada $\mathrm{pH}$ 4-6 $\left(\right.$ Gsianturi, 2002) ${ }^{8}$. Dalam suasana asam dekstrin yang merupakan oligosakarida akan menjadi lebih lunak sehingga pembentukan salut atau pelindung menjadi lebih tipis. Lapisan pelindung atau penyalut yang tipis tidak dapat menahan panas dari alat spray dryer dengan baik sehingga bakteri yang ada didalamnya tidak dapat bertahan hidup.

Pada perlakuan dengan penambahan jus markisa, Lactobacillus A17 memiliki viabilitas setelah enkapsulasi dan 2 minggu setelah enkapsulasi yang lebih tinggi dengan berbagai konsentrasi dekstrin dibandingkan dengan Lactobacillus Mar8, sedangkan pada konsentrasi dekstrin $10 \%$ viabilitas Lactobacillus Mar 8 lebih tinggi dibandingkan dengan viabilitas dari Lactobacillus A17 namun secara statistik konsentrasi dektrin 10\% tidak memberikan perbedaan yang nyata. Nilai rata-rata Log jumlah viabilitas Lactobacillus Mar 8 dan A17 setelah enkapsulasi sebesar 7,32 Log10 Cfu/g dan 7,07 Log10 Cfu/g dan nilai rata-rata Log jumlah viabilitas 2 minggu setelah enkapsulasi sebesar 8,59 Log10 Cfu/g dan 7,28 Log10 Cfu/g, hal ini merupakan konsentrasi optimum untuk L. plantarum Mar 8, begitu juga dengan Lactobacillus A17. Viabilitas dipengaruhi oleh konsentrasi penyalut (dekstrin). Penyalut dengan konsentrasi yang rendah tidak dapat melindungi bakteri dengan baik dari panas, sedangkan konsentrasi penyalut yang tinggi menyebabkan serbuk yang dihasilkan lebih banyak sehingga jumlah koloni per gramnya akan semakin sedikit.

Pada proses enkapsulasi Lactobacillus tidak dapat tahan terhadap suhu tinggi, sehingga ditambahkan penyalut supaya sel dapat dilindungi dari panas. Temperatur optimal Lactobacillus lebih rendah dari $37^{\circ} \mathrm{C}$ (Frazier dan Westhoff, 1998)6.

Untuk mengetahui perbedaan dari tiap perlakuan, nilai viabilitas $L$. plantarum 
dianalisis dengan menggunakan SPSS for window versi.10. Hasil analisis statistik SPSS dengan taraf kepercayaan $(\square)=$ 0,05 menunjukkan bahwa, perbandingan Log jumlah koloni antara tiap perlakuan sebelum enkapsulasi, setelah enkapsulasi dan 2 minggu setelah enkapsulasi yang berbeda nyata. Log jumlah koloni sebelum enkapsulasi pada semua perlakuan berbeda nyata terhadap perlakuan $\mathrm{A}$ (kontrol).

Perbandingan hasil analisis data Log jumlah koloni pada tiap perlakuan adalah sebagai berikut :

Tabel 1. Bobot dan rendemen hasil enkapsulasi dari masing masing perlakuan

\begin{tabular}{|c|c|c|c|}
\hline No & Perlakuan & Bobot Akhir Spray drying (mg) & Rendemen (\%) \\
\hline 1 & Jus Markisa+Dekstrin 10\%(Kontrol) $\quad(\mathrm{A})$ & 4200 & 42 \\
\hline 2 & Mar8+Dekstrin10\%(tanpa jus markisa)(B) & 5823,8 & 52,24 \\
\hline 3 & Jus Markisa+Mar 8+ Dekstrin 2\% & 200 & 6,87 \\
\hline 4 & Jus Markisa+Mar 8+ Dekstrin 5\% & 3182 & 52,43 \\
\hline 5 & Jus Markisa+Mar 8+ Dekstrin 10\% (E) & 4605,9 & 41,08 \\
\hline 6 & Jus Markisa+Mar 8+ Dekstrin 15\% (F) & 5400 & 33,96 \\
\hline 7 & Jus Markisa+A17+ Dekstrin 2\% & 400 & 16,32 \\
\hline 8 & Jus Markisa+A17+ Dekstrin 5\% & 4736,7 & 86,93 \\
\hline 9 & Jus Markisa+A17+ Dekstrin 10\% & 4310,3 & 41,07 \\
\hline 10 & Jus Markisa+A17+ Dekstrin 15\% & 5649,6 & 36,48 \\
\hline
\end{tabular}

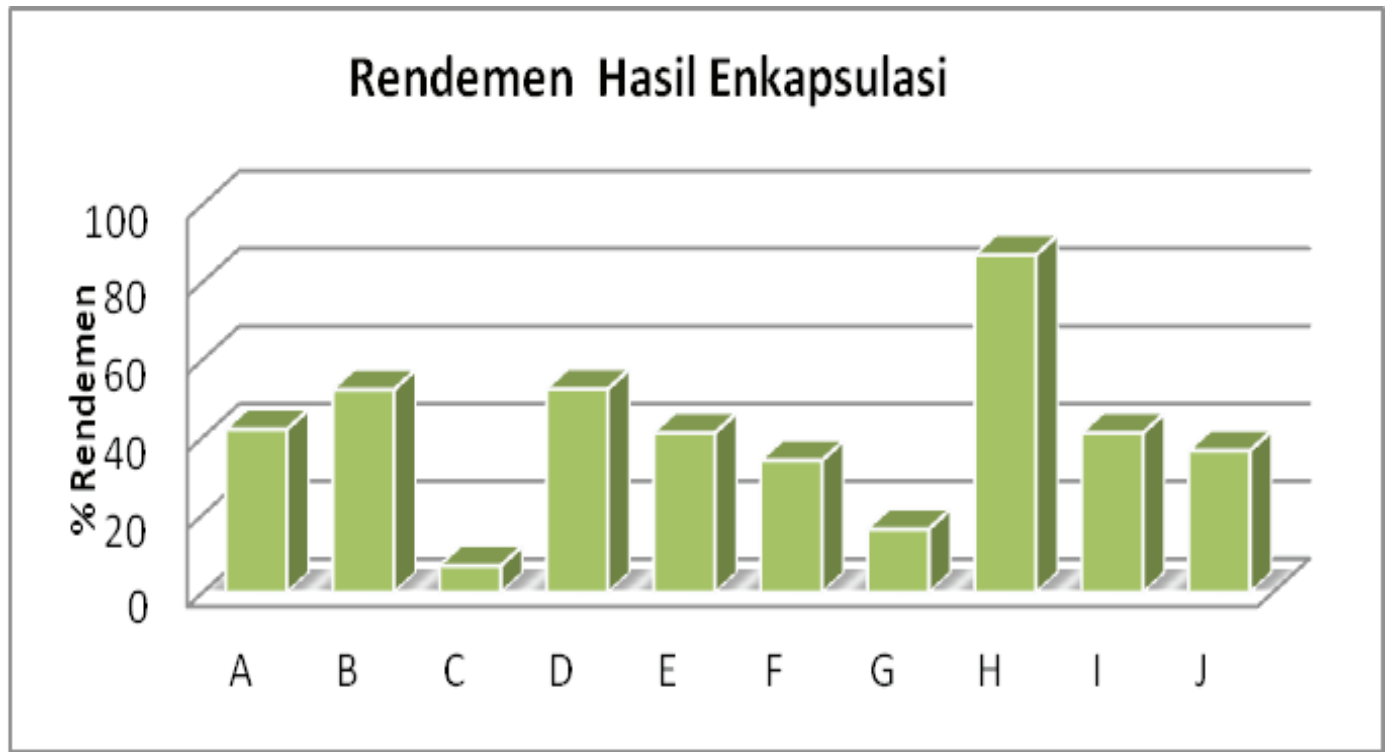

Gambar 1. Grafik Rendemen Hasil Enkapsulasi

Keterangan :
(A) Markisa + Dekstrin 10\% (Kontrol)
(F) Markisa + Mar $8+$ Dekstrin 15\%
(B) Mar8+Dekstrin 10\%(tanpa jus markisa)
(G) Markisa + A17+ Dekstrin 2\%
(C) Markisa + Mar $8+$ Dekstrin 2\%
(H) Markisa + A17+ Dekstrin 5\%
(D) Markisa + Mar $8+$ Dekstrin $5 \%$
(I) Markisa + A17+ Dekstrin 10\%
(E) Markisa + Mar $8+$ Dekstrin 10\%
(J) Markisa+A17+Dekstrin15\% 
Pada konsentrasi dekstrin 2\%. L. plantarum Mar 8 + markisa (C) dengan Lactobacillus A17 + markisa $(G)$ memiliki hasil analisis setelah enkapsulasi yang berbeda nyata, hal ini disebabkan karena setelah spray dryer Lactobacillus Mar 8 sama sekali tidak ada yang hidup, sedangkan pada Lactobacillus A17 masih dapat bertahan hidup pada proses pemanasan. Pada penyimpanan selama 2 minggu setelah tidak berbeda nyata dengan Lactobacillus Mar 8.

Pada konsentrasi dekstrin 5\%. $L$. plantarum Mar $8+$ markisa (D) dengan Lactobacillus A17 + markisa $(\mathrm{H})$ memiliki hasil analisis setelah enkapsulasi yang berbeda nyata, namun pada penyimpanan selama 2 minggu setelah enkapsulasi perbandingan hasil analisis antara keduanya tidak berbeda nyata.

Tabel 2. Hasil Analisis Log Jumlah Bakteri Antara Sebelum Enkapsulasi, Setelah Enkapsulasi dan 2 Minggu Setelah Enkapsulasi

\begin{tabular}{|c|c|c|c|c|c|c|}
\hline No & Perlakuan & Kultur & $\begin{array}{l}\text { Setelah } \\
\text { Spray drying }\end{array}$ & Rata2 & $\begin{array}{l}2 \text { Minggu Setelah Spray } \\
\text { drying (Suhu } 4 \circ C \text { ) }\end{array}$ & Rata2 \\
\hline & & \multicolumn{5}{|c|}{ Log10 cfu/g } \\
\hline \multirow[t]{2}{*}{1} & $\begin{array}{l}\text { Jus Markisa + Dekstrin } \\
10 \% \text { (Kontrol) }\end{array}$ & \multirow{2}{*}{10} & 0,000 & \multirow{2}{*}{0,00} & 0,000 & \multirow{2}{*}{0,00} \\
\hline & & & 0,000 & & 0,000 & \\
\hline \multirow[t]{2}{*}{2} & Mar 8 + Dekstrin 10\% & \multirow{2}{*}{10} & 8,255 & \multirow{2}{*}{8,31} & 9,260 & \multirow{2}{*}{9,28} \\
\hline & (tanpa jus markisa) & & 8,369 & & 9,290 & \\
\hline \multirow[t]{2}{*}{3} & Jus Markisa + Mar 8 & \multirow{2}{*}{10} & 0,000 & \multirow{2}{*}{0,00} & 0,000 & \multirow{2}{*}{0,00} \\
\hline & + Dekstrin $2 \%$ & & 0,000 & & 0,000 & \\
\hline \multirow[t]{2}{*}{4} & Jus Markisa + Mar 8 & \multirow{2}{*}{10} & 6,301 & \multirow{2}{*}{6,50} & 6,000 & \multirow{2}{*}{6,00} \\
\hline & + Dekstrin $5 \%$ & & 6,699 & & 6,000 & \\
\hline \multirow[t]{2}{*}{5} & Jus Markisa + Mar 8 & \multirow{2}{*}{10} & 7,301 & \multirow{2}{*}{7,32} & 8,230 & \multirow{2}{*}{8,59} \\
\hline & + Dekstrin $10 \%$ & & 7,342 & & 8,944 & \\
\hline \multirow[t]{2}{*}{6} & Jus Markisa + Mar 8 & \multirow{2}{*}{10} & 6,000 & \multirow{2}{*}{6,15} & 6,301 & \multirow{2}{*}{6,30} \\
\hline & + Dekstrin $15 \%$ & & 6,301 & & 6,301 & \\
\hline \multirow[t]{2}{*}{7} & Jus Markisa + A17 & \multirow{2}{*}{10} & 7,477 & \multirow{2}{*}{7,33} & 0,000 & \multirow{2}{*}{0,00} \\
\hline & + Dekstrin $2 \%$ & & 7,176 & & 0,000 & \\
\hline \multirow[t]{2}{*}{8} & Jus Markisa + A17 & \multirow{2}{*}{10} & 7,477 & \multirow{2}{*}{7,55} & 6,000 & \multirow{2}{*}{6,39} \\
\hline & + Dekstrin $5 \%$ & & 7,613 & & 6,778 & \\
\hline \multirow[t]{2}{*}{9} & Jus Markisa + A17 & \multirow{2}{*}{10} & 7,000 & 707 & 7,477 & o \\
\hline & + Dekstrin $10 \%$ & & 7,146 & I & 7,079 & 1,28 \\
\hline 10 & Jus Markisa + A17 & 10 & 7,000 & 78 & 7,000 & 700 \\
\hline & + Dekstrin $15 \%$ & 10 & 7,000 & 1,00 & 7,000 & (1,00 \\
\hline
\end{tabular}

enkapsulasi perbandingan hasil analisis antara keduanya tidak berbeda nyata, hal ini dikarenakan pada proses penyimpanan selama 2 minggu Lactobacillus A17 tidak dapat bertahan hidup, sehingga viabilitasnya
Pada konsentrasi dekstrin 10\%. L. plantarum Mar $8+$ markisa (E) dengan Lactobacillus A17 + markisa (I) memiliki hasil analisis setelah enkapsulasi yang tidak berbeda nyata, namun pada penyimpanan 


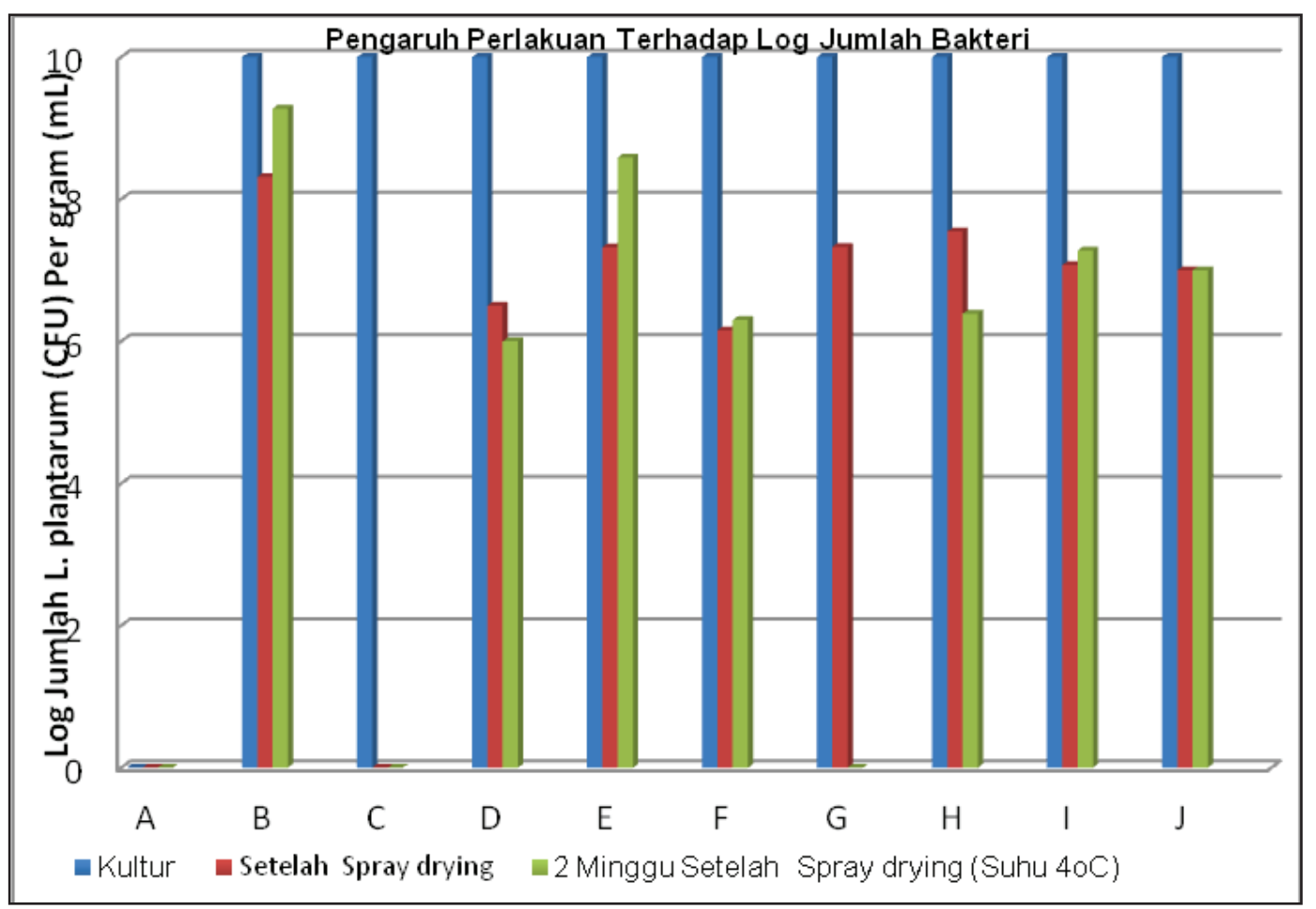

Gambar 2. Grafik pengaruh perlakuan terhadap Log jumlah bakteri

Keterangan :
(A) Markisa + Dekstrin 10\% (Kontrol)
(B) Mar $8+$ Dekstrin 10\% (tanpa markisa)
(C) Markisa + Mar $8+$ Dekstrin 2\%
(D) Markisa + Mar $8+$ Dekstrin $5 \%$
(E) Markisa + Mar $8+$ Dekstrin 10\%

selama 2 minggu setelah enkapsulasi perbandingan hasil analisis antara keduanya berbeda nyata.

Pada konsentrasi dekstrin 15\%. L. plantarum Mar $8+$ markisa $(F)$ dengan Lactobacillus A17 + markisa $(\mathrm{J})$ memiliki hasil analisis setelah enkapsulasi dan 2 minggu setelah enkapsulasi yang berbeda nyata.

Dengan konsentrasi dekstrin yang sama Lactobacillus A 17 memiliki viabilitas setelah enkapsulasi dan 2 minggu setelah enkapsulasi yang lebih tinggi dibandingkan dengan L. plantarum Mar 8, karena berdasarkan penelitian sebelumnya Lactobacillus A17 memiliki ketahanan terhadap $\mathrm{pH}$ rendah lebih baik dibandingkan dengan L. plantarum Mar 8.
(F) Markisa + Mar $8+$ Dekstrin 15\%

(G) Markisa + A $17+$ Dekstrin 2\%

(H) Markisa + A $17+$ Dekstrin 5\%

(I) Markisa + A $17+$ Dekstrin $10 \%$

(J) Markisa+A17+Dekstrin 15\%

\subsection{Hasil Uji Identifikasi Lactobacillus}

Setelah enkapsulasi dilakukan identifikasi kembali bakteri yang tumbuh. Hasil penelitian menunjukkan bahwa bakteri yang terdapat dalam serbuk setelah enkapsulasi adalah Lactobacillus dengan terbentuknya zona bening pada media karena Lactobacillus mampu mendegradasi $\mathrm{CaCO}_{3}$ yang kemudian digunakan sebagai bahan dalam proses metabolisme bakteri tersebut. Hasil uji katalase menunjukkan katalase negatif dengan tidak terbentuknya gelembung gas pada koloni dan sekitarnya, sedangkan pada pewarnaan gram Lactobacillus menunjukkan bakteri gram positif dengan memperlihatkan bakteri 
yang berwarna ungu, sehingga bakteri yang tumbuh setelah enkapsulasi merupakan bakteri yang sama dengan sebelum enkapsulasi yakni Lactobacillus Mar 8 dan A17.

\subsection{Hasil Perhitungan Waktu Simpan}

Pada Tabel 3. terlihat bahwa Lactobacillus A 17 (I) dan L. plantarum Mar 8 (E), waktu simpan untuk mencapai jumlah sel $106 \mathrm{Cfu} / \mathrm{g}$ yang paling lama yaitu pada konsentrasi dekstrin $10 \%$ selama 73,02 hari dan 14,63 hari. Waktu simpan paling panjang adalah pada Lactobacillus A17 dengan konsentrasi dekstrin $10 \%$.

Hasil penghitungan ini menggunakan rumus :

Nilai rata-rata Log jumlah viabilitas setelah enkapsulasi (N2) dan nilai rata-rata Log jumlah viabilitas 2 minggu (336 jam) setelah enkapsulasi (N1)

Menghitung waktu simpan (t) hingga mencapai jumlah sel $106 \mathrm{cfu} / \mathrm{g}$ :

$$
\square \log N 2-\log N 1 \square=k(t) / 2,303
$$

Waktu simpan pada setiap sampel berbeda-beda tergantung pada laju kematian sel, laju kematian ini berhubungan dengan media hidup sel tersebut. Bila perkembangan bakteri cepat maka nutrisi dalam mediapun akan cepat habis sehingga waktu simpannya pun akan pendek (Tabel 3).

\section{KESIMPULAN DAN SARAN}

\subsection{Kesimpulan}

Berdasarkan pada penelitian yang telah dilakukan, maka dapat disimpulkan bahwa pada L. plantarum Mar 8 dan A17 dengan penambahan dekstrin konsentrasi $10 \%$ menghasilkan viabilitas yang lebih tinggi dibandingkan dengan penambahan dekstrin pada konsentrasi $2 \%, 5 \%$, dan $15 \%$. Nilai rata-rata Log jumlah viabilitas dari L. plantarum Mar 8 setelah enkapsulasi sebesar 7,32 Log10 Cfu/g dan nilai ratarata Log jumlah viabilitas 2 minggu setelah enkapsulasi sebesar 8,59 Log10Cfu/g. Sedangkan pada Lactobacillus A 17 nilai rata-rata Log jumlah viabilitas setelah enkapsulasi sebesar 7,07Log10 Cfu/g dan nilai rata-rata Log jumlah viabilitas 2 minggu setelah enkapsulasi sebesar 7,28 Log10 Cfu/g. Lactobacillus A17 konsentrasi dekstrin $10 \%$ probiotiknya masih dapat disimpan sampai 73,02 hari dengan laju kematian 0,00141Cfu/g/jam sedangkan L.plantarum Mar8 hanya 14,63 hari dengan laju kematian 0,00867 Cfu/g/jam,sehingga

Table 3. Waktu Simpan Probiotik

\begin{tabular}{|l|l|c|c|}
\hline No & \multicolumn{1}{|c|}{ Perlakuan } & $\begin{array}{c}\text { Laju Kematian (k) } \\
\text { (Cfu/g/jam) }\end{array}$ & $\begin{array}{c}\text { Waktu Simpan } \\
\text { Probiotik (Hari) }\end{array}$ \\
\hline 1 & Jus Markisa+ Mar 8+ Dekstrin 2\% & Negatif & Negatif \\
\hline 2 & Jus Markisa+ A 17+ Dekstrin 2\% & 0,05 & 2,55 \\
\hline 3 & Jus Markisa+ Mar 8+ Dekstrin 5\% & 0,00343 & 13,99 \\
\hline 4 & Jus Markisa+ A 17+ Dekstrin 5\% & 0,00792 & 18,72 \\
\hline 5 & Jus Markisa+ Mar 8+ Dekstrin 10\% & 0,00867 & 14,63 \\
\hline 6 & Jus Markisa+ A 17+ Dekstrin 10\% & 0,00141 & 73,02 \\
\hline 7 & Jus Markisa+ Mar 8+ Dekstrin 15\% & 0,00281 & 5,16 \\
\hline 8 & Jus Markisa+ A 17+ Dekstrin 15\% & 0 & Tidak terhingga \\
\hline 9 & Mar 8 + Dekstrin 10\% (Pembanding) & 0,0066 & 36,98 \\
\hline 10 & Jus Markisa + Dekstrin 10\% (Kontrol) & Negatif & Negatif \\
\hline
\end{tabular}


Lactobacillus A17 dengan konsentrasi dektrin $10 \%$ menggunakan jus markisa sebagai penambah rasa dapat direkomendasikan sebagai probiotik dalam bentuk sediaan serbuk.

\section{Saran}

Perlu dilakukan penelitian lebih lanjut mengenai enkapsulasi Lactobacillus dan parameter-parameter yang mendukung sehingga menghasilkan produk yang lebih baik berkualitas dengan jumlah viabilitas yang tinggi, dan dan masa simpan yang panjang, selain itu perlu dilakukan penelitian lanjutan mengenai pengolahan serbuk hasil enkapsulasi agar dapat dikonsumsi masyarakat dengan bentuk sediaan yang lebih praktis dan lebih disukai.

\section{DAFTAR PUSTAKA}

1. Dunne,C. L. Mahony, L. Murphy, G. Thornton, D. Morrissey, S. Halloran, M. Feeney, S. Flynn, G. Fitzgerald, C. Daly, B. Kiely, G. Sullivan, F. Shanahan and J. K. Collins. 2001. In Vitro Selection criteria for probiotic of human origin:correlation with in vivo finding 1-4. Am.J.CLin Nutr. 2001:73 (suppl):386S-92S

2. Segorous, D.PMaragkoudakis, K. Petraki,M.Gonzalez,E.Eriotou,S. Michopoulos, G.alantzoulos, E.Tsakalidou and A.Mentis. 2004. In Vitro and In Vivo Inhibition of Helicobacter pulory by Lactobacillus casei strain Shirota.Appl.Environ. Microbiol.Vol 70(1):518-526

3. Lisal, J. S. 2005. Konsep Probiotik dan Prebiotik untuk Modulasi Mikrobiota Usus Besar. J. Med. Nus. 26(4) : 259262.

4. Tjay, T.H. dan K. Raharja. 2002. Obat-obat Penting Edisi Kelima. PT Elex Media Komputindo Kelompok Gramedia : Jakarta
5. Fuller, R. 1989. Probiotics in Man and Animals. Horizon Scientific Press : Norfolk, England.

6. Yukuchi, H., T. Goto, and S. Okogoni. 1992. Fermented Food. 2nd Edition. Elsevier Applied Science Publisher Ltd : London.

7. Surono, S. I. 2004. Probiotik Susu Fermentasi dan Kesehatan. PT Tri Cipta Karya : Jakarta.

8. Isolauri, E., Y. Sutas, P. Kankaanpaa, H. Arvilommi and S. Salminen. 2001. Probiotics: effects on immunity1-3 .Am. J.Clin. Nutr 2001:73 (Suppl):444S-50S

9. Branen, A. L. 1993. Antimicrobials in Food. 2nd Edition. Marcell Dekker. Inc., New York

10. Costilow, R. N. 1981. Manual of Methods for General Bacteriology. American Society for Microbiology : Washington D. C

11. Gsianturi. 2002. Probiotik dan Prebiotik untuk Kesehatan. Kompas, Minggu, 27 Januari 2002

12. James, R., C. Lazdunski, and F. Pattus. 1992. Bacteriocins, Microcins, and Lantibiotics. Springer-Verlag : Berlin, Heidelberg.

13. Jenie, B. S. L. dan S. E. Rini. 1995. Aktivitas Anti Mikroba dari Beberapa Spesies Lactobacillus Terhadap Mikroba Patogen dan Perusak Makanan, Buletin Teknol. Ind. Pangan. 6(2) : 46-50

14. Molin, G. 2001. Probiotics in foods not containing milk or milk constituents, with special reference to Lactobacillus plantarum 299v1-3 .Am. J.Clin. Nutr.2001: 73 (Suppl): 380S-5S

15. Tamime, A. Y. and R. K. Robinson. 1989. Yoghurt Science and Tecnology. Pergamon Press : Oxford.

16. Risch, S.J., 1995. Encapsulation: Overview of Uses and Techniques. Di Dalam S.J. Risch and G.A. Reineccius (Eds.). Encapsulation and Controlled Release of Food Ingredients. American Chemical Society, Washington, DC. 
17. Masters, K. 1979. Spray Drying Handbook. John Wiley and Sons : New York.

18. Potter, N.N. 1980. Food Science. The Avi Pub. Co. Inc., Wesport, conneticut.

19. Lewis, J. E. 1993. Cheese Starter. Development and Application of the Lewis System. Elsevier Applied Science Publisher : London.

20. Rahmat. 1988. Pembuatan Dan Karakterisasi Tepung Sari Buah Markisa. Fakultas Teknologi Pertanian Institut Pertanian Bogor : Bogor

21. James, E.F. Reynold and A.B. Prasad. 1987. Martindale : The Complete Drug Reference. The Pharmaceutical Press : London.

22. Anonymous. 1998. Pasca Panen Markisa. Departemen Pertanian Balai Pengkajian Teknologi Pertanian (BPTP) : Sukarami.

23. Brooks, G.F, J.F. Buteel, dan A. S.Morsedan. 2001. Mikrobiologi kedokteran edisi pertama. Penerjemah dan Editor : Bagian Mikrobiologi Fakultas Kedokteran Universitas Erlangga. Salemba Media : Jakarta.
24. Leslie, S. B., E. Israeli, B. Lighthart, J. H. Crowe dan L. M. Crowe. 2003. Threhalose and Sucrose Protect both Membranes and Proteins in Intact Bacteria During Drying . Applied and Environmental Microbiology, 95 (1): 3592-3597.

25. Zamora, L. M., C. Carretero and D. Pares. 2006. Comparative Survival Rates of Lactic Acid Bacteria Isolate Froom Blood, Following Spray drying ang Freeze drying. Food Scince Technology International. 12(1) : 77-84

26. Lay, Bibiana. 1994. Analisis Mikroba Dilaboratorium. Pt. Raja Grafindo Persada. Jakarta.

27. Hadioetomo, R.S. 1985. Mikrobiologi Pangan dalam Praktek Teknik dan Prosedur Dasar Laboratorium. PT Gramedia : Jakarta.28. Svenssan, U. 1999. Industrial Prospektif. In : G. W. Tanlok (Ed). Probiotick, a Critical. Review. Horison Scient Fisik Producer : Angland

29. Frazier, W. B., and D. C. Westhoff. 1998. Food Microbiology. Third edition. Mc Graw-Hill, inc : New York. 539 hlm. 